\title{
The chalcone derivative Chana 1 protects against amyloid $\beta$ peptide-induced oxidative stress and cognitive impairment
}

\author{
JIEUN KWAK ${ }^{1,2 *}$, MI-JEONG KIM ${ }^{3 *}$, KYUNG-CHUL CHOI ${ }^{4}$, HYO-KYUNG CHOI $^{5}$, \\ WOOJIN JUN ${ }^{6}$, HYUN-JIN PARK ${ }^{2}$, YOO-HYUN LEE ${ }^{1}$ and HO-GEUN YOON ${ }^{5}$
}

\begin{abstract}
${ }^{1}$ Department of Food Science and Nutrition, The University of Suwon, Hwaseong; ${ }^{2}$ School of Life Science and Biotechnology, Korea University, Seoul, Republic of Korea; ${ }^{3}$ Research Institute, National Center for Geriatrics and Gerontology (NCGG), Obu city, Japan; ${ }^{4}$ Department of Medicine, Graduate School, University of Ulsan College of Medicine, Seoul; ${ }^{5}$ Department of Biochemistry and Molecular Biology, Yonsei University College of Medicine, Seoul; ${ }^{6}$ Department of Food and Nutrition, Chonnam National University, Gwangju, Republic of Korea
\end{abstract}

Received January 29, 2012; Accepted March 30, 2012

DOI: $10.3892 / \mathrm{ijmm} .2012 .984$

\begin{abstract}
Alzheimer's disease (AD) is the most common neurodegenerative disease to cause dementia in the elderly. Amyloid $\beta$ (A $\beta$ )-peptide induced oxidative stress causes the initiation and progression of AD. Recently, new chalcone derivatives termed the Chana series were synthesized. Among them, Chana 1 showed high free radical scavenging activity (72.5\%), as measured by a DPPH (1,1-diphenyl-2-picrylhydrazyl) assay. In this study, we investigated the effect of Chana 1 against $A \beta$-induced cytotoxicity and cognitive deficits. Additionally, we sought to estimate the lethal dose, $50 \%$ $\left(\mathrm{LD}_{50}\right)$ of Chana 1 in mice using an acute oral toxicity test. We found that Chana 1 significantly protected against $\mathrm{A} \beta$-induced neuronal cell death in PC12 cells. Oral administration of Chana 1 at a dose of $50 \mathrm{mg} / \mathrm{kg}$ body weight/day significantly improved $\mathrm{A} \beta$-induced learning and memory impairment in mice, as measured in Y-maze and passive avoidance tests. In acute toxicity tests, the $\mathrm{LD}_{50}$ in mice was determined to be $520.44 \mathrm{mg} / \mathrm{kg}$ body weight. The data are valuable for future studies and suggest that Chana 1 has therapeutic potential for the management of neurodegenerative disease.
\end{abstract}

Correspondence to: Dr Ho-Geun Yoon, Department of Biochemistry and Molecular Biology, Yonsei University College of Medicine, 134 Shinchon-dong, Seodaemun-gu, Seoul 120-752, Republic of Korea E-mail: yhgeun@yuhs.ac

Dr Yoo-Hyun Lee, Department of Food Science and Nutrition, The University of Suwon, Hwaseong, Kyonggi-do 445-743, Republic of Korea

E-mail: creamut@suwon.ac.kr

*Contributed equally

Key words: Alzheimer's disease, chalcone derivative, oxidative stress, cognitive impairment, neuroprotective effect, $\beta$-amyloid, lethal dose 50

\section{Introduction}

Alzheimer's disease (AD) is the most frequent cause of dementia in the elderly and the number of AD cases continues to increase. AD is a progressive, irreversible neurodegenerative disease characterized by neurofibrillary tangles and senile plaques caused by deposits of amyloid $\beta(\mathrm{A} \beta)$ in the brain. $\mathrm{A} \beta$ protein and oxidative stress are believed to have crucial roles in the development of AD. A $\beta$ is a source of free radicals itself in the presence of metal ions (1) or a pre-form of an aggregated $A \beta$ that induces neurotoxicity by oxidative stress (2). The brain is particularly vulnerable to oxidative stress because of its elevated consumption of oxygen, high levels of polyunsaturated fatty acids, and relatively low levels of antioxidants $(3,4)$. Several studies have observed increased protein oxidation (5) and reactive oxygen species (ROS) formation (6) in the brain tissue of $\mathrm{AD}$ patients. Moreover, $\mathrm{A} \beta$ is considered a cause of lipid peroxidation in brain cell membranes that may also contribute to neurodegeneration in $\operatorname{AD}$ brains $(7,8)$. These data indicate that oxidative stress is an early event in AD pathogenesis.

In normal cellular metabolism, cells produce antioxidant enzymes such as catalase, superoxide dismutase, and glutathione peroxidase as a part of a cellular defense system against ROS-mediated cellular damage (9). However, the endogenous antioxidant defense system becomes impaired with excessive generations of ROS and free radicals, such as is caused by increasing $A \beta$ levels (10). These events make the brain vulnerable to $A \beta$-induced toxic effects and are involved in the pathogenesis of most of the neurodegenerative disorders, including AD. Multiple studies have shown that antioxidants and free radical scavengers inhibit $A \beta$-induced neurotoxicity (11-13) and antioxidant substances improve spatial cognition and retard AD pathogenesis $(14,15)$.

Most polyphenols have strong antioxidant activity by reacting as hydrogen- or electron-donating agents, in addition to having metal ion chelating properties due to their phenol groups (16). Retrochalcone is an unusual phenolic compound that is structurally distinguished from normal chalcones by the 
lack of oxygen functionalities at $C^{\prime}-2$ and $C^{\prime}-6$. Recent studies have described the dynamic activities, including antioxidative and superoxide scavenging activity (17-21) of natural or synthesized retrochalcones.

In our previous study (22), we synthesized Chana 30, a retrochalcone derived via structural modification of a natural retrochalcone from licorice, and found the neuroprotective effect of Chana 30 was due to its potent free radical scavenging effect. In this study, we evaluated a new synthetic retrochalcone, Chana 1 that shows high antioxidant activity as compared with Chana 30. We investigated whether Chana 1 protects against neuronal cell death and cognitive impairment induced by $\mathrm{A} \beta$ peptide in vitro and in vivo and found a decrease in oxidative damage with improved cognition observed in mice. Additionally, we carried out an acute toxicity test to determine the oral lethal dose, $50 \%\left(\mathrm{LD}_{50}\right)$ in mice. Our data suggest that Chana 1 is a possible chemotherapeutic agent for neurodegenerative disease.

\section{Materials and methods}

Materials. Fetal bovine serum (FBS), trypsin-ethylenediaminetetraacetic acid, and penicillin-streptomycin were purchased from Gibco-BRL (Gaithersburg, MD, USA). MTT [3-(4,5-dimethylthiazol-2-yl)-2,5-diphenyltetrazolium bromide] was purchased from Sigma-Aldrich (St. Louis, MO, USA). $A \beta_{1-42}$ and $A \beta_{42-1}$ were purchased from Bachem (Bubendorf, Switzerland). All other chemicals were purchased from Sigma-Aldrich.

Cell culture. The rat pheochromocytoma PC12 cell line was obtained from the American Type Culture Collection (ATCC, Manassas, VA, USA). Cells were maintained in RPMI-1640 media containing $10 \%$ heat-inactivated $\mathrm{FBS}$ and $1 \%$ penicillin-streptomycin. Cells were incubated at $37^{\circ} \mathrm{C}$ in a $5 \% \mathrm{CO}_{2}$ atmosphere with $95 \%$ humidity.

DPPH (1,1-diphenyl-2-picrylhydrazyl) assay. The free radical scavenging activity of Chana 1 was assayed using the DPPH method, a modification of the Blois method (23). Briefly, $10 \mathrm{mM}$ of sample was dissolved in methanol and serially diluted to 5 , $10,20,50$ and $100 \mu \mathrm{M}$ with ethanol. DPPH $(0.25 \mathrm{mM})$ was mixed with each diluted sample, incubated for $30 \mathrm{~min}$ at room temperature, and the optical density was measured at $517 \mathrm{~nm}$. An equal volume of ethanol alone was added to the control tube. The DPPH radical scavenging activity was calculated according to the following equation: $\%$ scavenging activity = $\left[\left(A_{0}-A_{1}\right) / A_{0}\right] \times 100$, where $A_{0}$ is the absorbance of control and $A_{1}$ is the absorbance of the sample.

Cell viability assay. An MTT assay was performed to test the cytotoxicity or neuroprotective effects of Chana 1 in PC12 cells. Briefly, cells $\left(1 \times 10^{4}\right.$ cells/well) were seeded in 96-well culture plates and treated with various concentrations of Chana 1 for $24 \mathrm{~h}$. Cell viability was expressed as a relative percentage against control cultures. For the measurement of A $\beta$-induced neuroprotective activity, various concentrations of Chana 1 were added to cells for $24 \mathrm{~h}$ before treatment with $A \beta$. The positive control drug, selegiline, currently being used to treat Alzheimer's, was evaluated in the same manner for comparison. MTT solution $(2.0 \mathrm{mg} / \mathrm{ml})$ was added to each well and incubated for $4 \mathrm{~h}$ at $37^{\circ} \mathrm{C}$. Media was removed and the formazan crystals obtained were solubilized in $100 \mu 1$ dimethyl sulfoxide (DMSO). The optical density was determined (excitation at $570 \mathrm{~nm}$, emission at $630 \mathrm{~nm}$ ) using a microplate reader (Model 550; Bio-Rad Laboratories, Hercules, CA, USA).

Animals. ICR male mice (5-weeks-old) were obtained from Samtako Co. (Osan, Korea) and acclimated for 1 week prior to the initiation of the experiments. Animals were housed in a room maintained at a temperature of $23 \pm 1^{\circ} \mathrm{C}$ with $60 \pm 10 \%$ humidity and a controlled $12 \mathrm{~h}$ light/dark cycle. They were supplied with a standard pellet diet (Purina Korea) and tap water ad libitum. Mice were divided into 6 groups with 8 animals in each group: i) control group, ii) $\mathrm{A} \beta$-injected group, iii) and iv) $A \beta$-injected with Chana 1 added, 20 or $50 \mathrm{mg} / \mathrm{kg}$ body weight, respectively, and v) and vi) $\mathrm{A} \beta$-injected with selegiline $(3.0 \mathrm{mg} / \mathrm{kg}$ body weight) and Aricept $(1.0 \mathrm{mg} / \mathrm{kg}$ body weight), respectively. Chana 1 was dissolved in tap water and orally administered daily for 34 days. After administration of Chana 1 or control drugs for 28 days, $A \beta_{1-42}$ or $A \beta_{42-1}$ was administered by intracerebroventricular injection (410 pmol per mouse) according to Chauhan's method (24). The control group was injected with $A \beta_{42-1}$, the non-toxic reverse fragment. $\mathrm{A} \beta$ peptides were dissolved in phosphate-buffered saline, and pre-incubated at $37^{\circ} \mathrm{C}$ for 5 days to allow fibril formation. The $10 \mu 1$ peptides were injected directly using a Hamilton microsyringe ( $25 \mathrm{G}$ needle) into the third ventricle, $0.25 \mathrm{~mm}$ posterior to the bregma at a depth of $2.5 \mathrm{~mm}$ (anteroposterior, $-0.25 \mathrm{~mm}$; mediolateral, $0 \mathrm{~mm}$; dorsal ventral, $2.5 \mathrm{~mm}$ relative to the bregma). All experiments were conducted in accordance with the guidelines of the Committee on Care and Use of Laboratory Animals of Yonsei University.

Y-maze test. A Y-maze was used to test for ameliorating effects of Chana 1 in mice on spatial working memory 4 days after $A \beta$ injection. The used maze was $33 \mathrm{~cm}$ long, $15 \mathrm{~cm}$ high, and $10 \mathrm{~cm}$ wide with the arms symmetrically disposed. Each mouse was initially placed within one arm and number of arm entries was recorded manually during an 8 -min period. The percentage of alternation was determined using the following equation: $\%$ alternation $=[($ number of alternations $) /($ total arm entries-2)] x 100 (25).

Passive avoidance test. A passive avoidance test was used to evaluate the effects of the Chana 1 on learning and memory (26). The test was carried out 6 days after $A \beta$ injection. A two-compartment step-through passive avoidance apparatus (Model PACS-30; Columbus Instruments International, Columbus, OH, USA) was used. The apparatus was divided into two chambers of equal size $(23.5 \times 15.5 \times 15.5 \mathrm{~cm})$, one illuminated and one dark. During the training session, mice were placed in the illuminated compartment and the door was raised to allow the mice to enter the dark compartment. When the mice entered the dark compartment, the door was closed and an electrical foot shock $(0.5 \mathrm{~mA}$ for $1 \mathrm{sec})$ was delivered. Control mice were also subjected to electric foot shock when entering the dark compartment. The testing session was performed 1 day after the training session. The mice were 
<smiles>O=C(/C=C/c1ccccc1)c1ccc(I)cc1</smiles>

B<smiles>COc1cc(O)ccc1/C=C/C(=N)c1ccc(O)cc1</smiles>

$\mathrm{C}_{16} \mathrm{H}_{15} \mathrm{NO}_{4}$

Mol. Wt.: 285.29

Figure 1. Chemical structures of chalcones. (A) Natural chalcone backbone and (B) synthesized Chana 1.

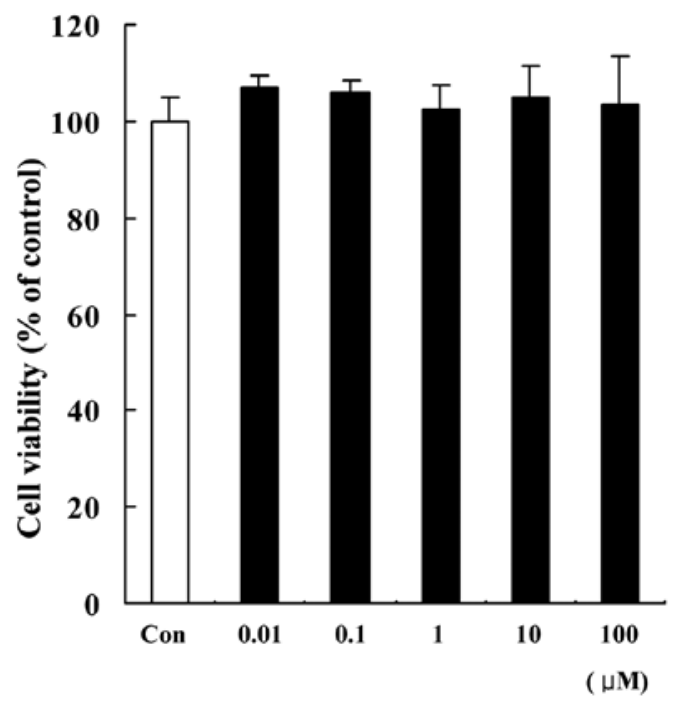

Figure 2. Effects of Chana 1 in the PC12 cell viability assay. PC12 cells were treated with Chana 1 of various concentrations $(0.01-100 \mu \mathrm{M})$ in serum-free media for $24 \mathrm{~h}$. The cell viability was determined by the MTT assay, and expressed as the mean percentage of viable cells compared with the untreated cells. The data are the mean $\pm \mathrm{SE}(\mathrm{n}=5)$.

again placed in the bright compartment and the latency time to enter the dark compartment was recorded (up to $300 \mathrm{sec}$ ).

Evaluation of acute oral toxicity. Acute oral toxicity $\left(\mathrm{LD}_{50}\right)$ was evaluated by a mouse lethality assay. The acute toxicity test was performed according to the Organisation for Economic Co-operation and Development guidelines (27). Mice were randomly assigned to 5 groups of 10 animals each. The control group received a mixture of saline and $0.5 \%$ carboxymethyl cellulose (CMC) only. A mixture of saline and $0.5 \%$ CMC with 5\% DMSO was used for the preparation of the different doses of Chana 1 (300, 500 and $700 \mathrm{mg} / \mathrm{kg}$ body weight), that was used as a vehicle. All treatment was given by gavage for oral administration. The mice were observed $1 \mathrm{~h}$ after a single administration of Chana 1 and subsequently monitored until $96 \mathrm{~h}$ post treatment. Acute toxicity was calculated as the dose required (in $\mathrm{mg} / \mathrm{kg}$ body weight) to cause death in $50 \%$ of animals $\left(\mathrm{LD}_{50}\right)$ using a Sigma plot program.

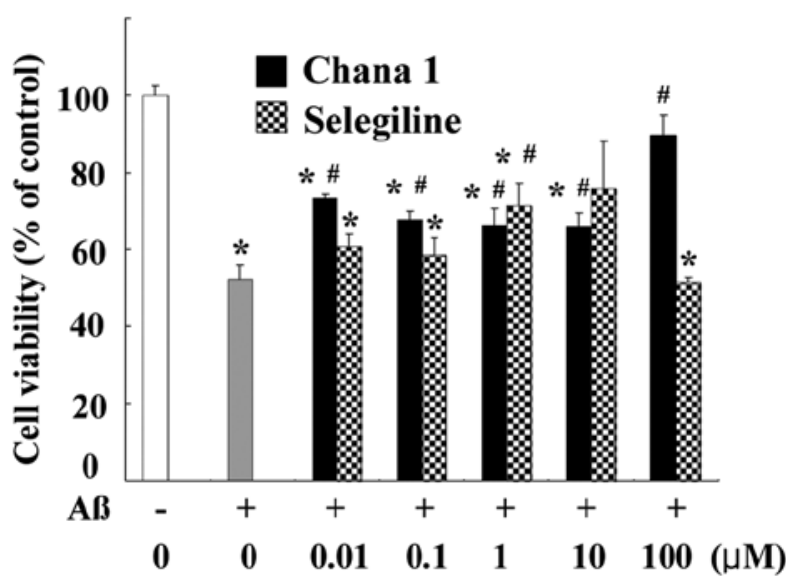

Figure 3. Protective effects of the Chana 1 against $A \beta_{1-42}$-induced cell damage. Cell viability of Chana 1 was evaluated using the MTT assay. All groups were treated with $25 \mu \mathrm{M} \mathrm{A} \beta_{1-42}$ except for the control group. Selegiline was used as a positive control at the same concentrations. Chana 1 and selegiline were pre-incubated at various concentrations $(0.01-100 \mu \mathrm{M})$ in serum-free media for $24 \mathrm{~h}$ before the addition of $\mathrm{A} \beta$ peptide. Cell viability is expressed as the mean percentage of viable cells compared with the untreated cells. The data are the mean $\pm \mathrm{SE}(\mathrm{n}=5)$. ${ }^{*} \mathrm{P}<0.05$ vs. the control group; ${ }^{*} \mathrm{P}<0.05$ vs. the $\mathrm{A} \beta_{1-42}$-peptide treated group.

Statistical analyses. All results are expressed as means \pm standard error. Statistical comparisons were performed using a Student's t-test. A P-value $<0.05$ was considered to indicate statistical significance.

\section{Results}

Cytotoxicity of Chana 1 in PC12 cells. In our previous study, we screened the synthetic chalcone series using the free radical scavenging assay. This assay is considered a preliminary screening tool to determine whether compounds have scavenging activity against oxygen species (28). In this study, Chana 1 was found to have potent DPPH radical scavenging activity with an activity of $76.5 \%$. The chemical structure of synthetic Chana 1 is shown in Fig. 1B. Next, we conducted an MTT assay to evaluate the effect of Chana 1 on cell viability. PC12 cells were incubated with varying concentrations $(0.01-100 \mu \mathrm{M})$ of Chana 1 for $24 \mathrm{~h}$. Chana 1 did not exhibit cytotoxicity in PC12 cells at any of the concentrations tested (Fig. 2).

Protective effect of Chana 1 against $A \beta$-induced cell cytotoxicity in PC12 cells. To evaluate the effect of Chana 1 on A $\beta$-induced PC12 cell death, we also performed MTT assays in cells treated with varying concentrations of Chana 1. Cells treated with $A \beta$ demonstrated significantly decreased cell viability as compared with control cells (Fig. 3). However, pretreating the cells with Chana 1 significantly protected against $\mathrm{A} \beta$-induced cell death (up to $89.57 \%$ ) at a concentration of $100 \mu \mathrm{M}$. Moreover, the protective effect of Chana 1 was significantly higher than that of selegiline. These results suggest that Chana 1 can protect against the cell damage caused by $\mathrm{A} \beta$-induced cytotoxicity.

Ameliorative effects against $A \beta$-induced memory impairment of Chana 1 in mice. Given the protective activity of Chana 1 


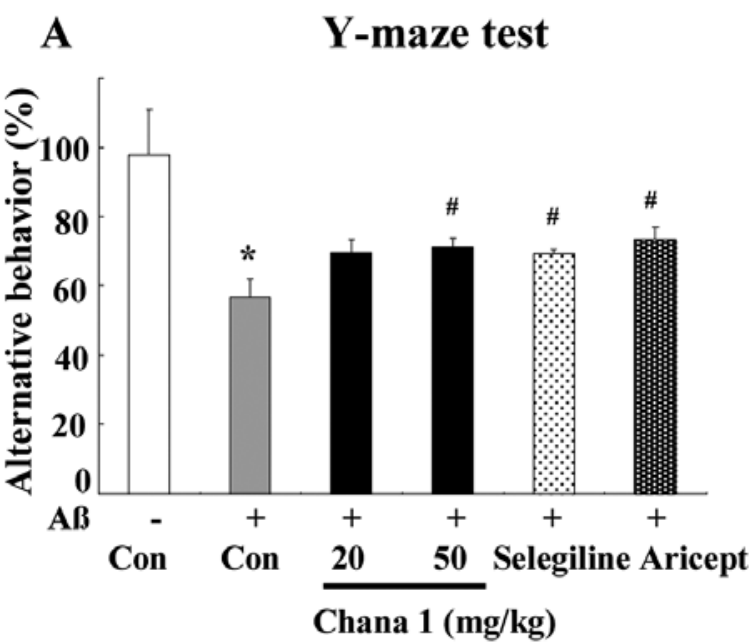

\section{B Passive avoidance test}

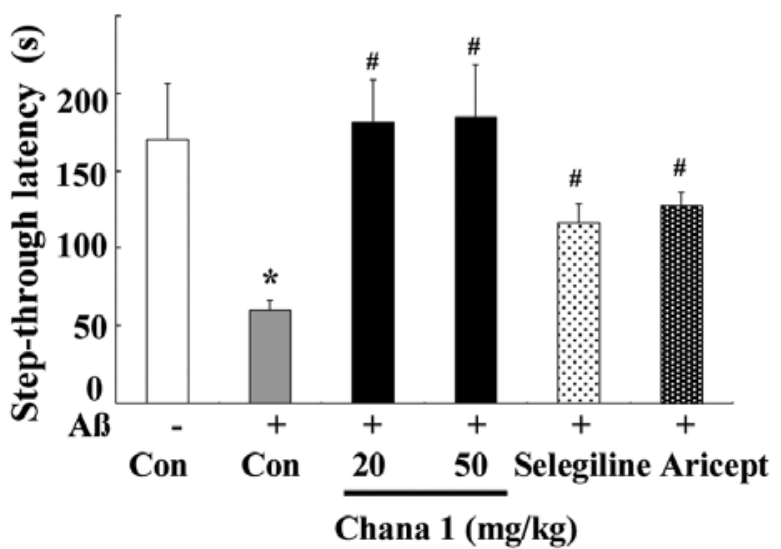

Figure 4. Effects of the Chana 1 against A $\beta$-induced memory impairment in mice. (A) Y-maze test was carried out for spontaneous alternation behavior, which is regarded as a measurement of spatial memory in $A \beta$-injected mice. (B) Step-through latency (s) was evaluated for a passive avoidance task in A $\beta$-injected memory-impairment mice. Chana 1 (20 or $50 \mathrm{mg} / \mathrm{kg}$ b.w.), selegiline (3 mg/kg b.w.) or Aricept ( $1 \mathrm{mg} / \mathrm{kg}$ b.w.) were given by oral administration for $28 \mathrm{days}$ before $\mathrm{A} \beta_{1-42}$-injection; control mice were injected with $\mathrm{A} \beta_{42-1}$. The data are the mean $\pm \mathrm{SE}(\mathrm{n}=8)$. ${ }^{*} \mathrm{P}<0.05$ vs. $\mathrm{A} \beta_{42-1}$-injected control group; ${ }^{\#} \mathrm{P}<0.05$ vs. $\mathrm{A} \beta_{1-42^{-}}$ injected group.

Table I. Effects of oral administration of Chana 1 on body weight (b.w.) through at the experiment.

\begin{tabular}{lcc}
\hline Experimental group & Initial b.w. (g) & Final b.w. (g) \\
\hline Control & $20.3 \pm 1.3$ & $35.8 \pm 0.6$ \\
$\mathrm{~A} \beta_{1-42}$ & $20.3 \pm 1.4$ & $36.7 \pm 0.6$ \\
$\mathrm{~A} \beta_{1-42}+$ Chana $1(20 \mathrm{mg} / \mathrm{kg}$ b.w.) & $21.0 \pm 1.4$ & $35.5 \pm 0.6$ \\
$\mathrm{~A} \beta_{1-42}+$ Chana $1(50 \mathrm{mg} / \mathrm{kg}$ b.w.) & $19.3 \pm 1.4$ & $36.7 \pm 1.0$ \\
$\mathrm{~A} \beta_{1-42}+$ selegiline (3 mg/kg b.w.) & $19.8 \pm 1.4$ & $37.0 \pm 0.7$ \\
$\mathrm{~A} \beta_{1-42}+$ Aricept $(1 \mathrm{mg} / \mathrm{kg}$ b.w.) & $20.0 \pm 1.4$ & $36.0 \pm 0.7$ \\
\hline
\end{tabular}

Control mice were injected with $A \beta_{42-1}$. The data are the mean $\pm \mathrm{SE}(\mathrm{n}=8)$.

Table II. Effects of Chana 1 in mice after acute oral administration.

\begin{tabular}{|c|c|c|c|c|}
\hline \multirow[b]{2}{*}{ Treatment dose $(\mathrm{mg} / \mathrm{kg})$} & \multicolumn{2}{|c|}{ Mice } & \multicolumn{2}{|r|}{ Effects } \\
\hline & Gender & $\mathrm{D} / \mathrm{T}$ & Mortality latency (h) & Symptoms of toxicity \\
\hline \multirow[t]{2}{*}{ Control } & M & $0 / 5$ & - & None \\
\hline & $\mathrm{F}$ & $0 / 5$ & - & None \\
\hline \multirow[t]{2}{*}{ Vehicle } & M & $0 / 5$ & - & None \\
\hline & $\mathrm{F}$ & $0 / 5$ & - & None \\
\hline \multirow[t]{2}{*}{300} & M & $1 / 5$ & $>6,<24$ & Slow movement, eye mucus \\
\hline & $\mathrm{F}$ & $3 / 5$ & $>24,<27$ & Lying down, eye mucus \\
\hline \multirow[t]{2}{*}{500} & M & $4 / 5$ & $>6,<24$ & Slow movement, hair bristling \\
\hline & $\mathrm{F}$ & $1 / 5$ & $>27,<31$ & Slow movement, hair bristling \\
\hline \multirow[t]{2}{*}{700} & M & $4 / 5$ & $>6,<24$ & Lying down, eye mucus, hair bristling \\
\hline & $\mathrm{F}$ & $2 / 5$ & $>6,<24$ & Lying down, eye mucus, hair bristling \\
\hline
\end{tabular}

M, male; F, female; D/T, dead/total treated mice; mortality latency, time to death after the oral injection. 
in vitro, we performed an in vivo study to investigate the effects of Chana 1 on the learning and memory impairment in $\mathrm{A} \beta$-injected mice. We performed a Y-maze test to evaluate Chana 1 on the spatial working memory of mice. Spatial working memory is a form of short-term memory recognition measured by recording spontaneous alternation behavior. Selegiline and Aricept, are being used to treat Alzheimer's, were used as positive controls. We found that the spontaneous alternation behavior of the $\mathrm{A} \beta_{1-42}$-injected group was significantly lower than that of the control groups $(\mathrm{P}<0.05)$ (Fig. 4A). However, the reduced spatial working memory by $\mathrm{A} \beta_{1-42}$ treatment was significantly ameliorated by the administration of 20 and $50 \mathrm{mg} / \mathrm{kg}$ Chana 1 (12.9 and 14.2\%, respectively). There were no differences in the positive controls upon addition of Chana 1 . In addition, we evaluated learning ability by measuring the response latency in the step-through passive avoidance test. The behavior of the $A \beta_{1-42}$-injected group indicated significant damage as measured by the passive avoidance test. The step through latency (STL) of the control group and $\mathrm{A} \beta_{1-42}$-injected group were 170.3 and $60.0 \mathrm{sec}$, respectively. The Chana 1 treated group dramatically improved $A \beta$-induced memory impairment as measured by an increase in STL time (Fig. 4B). Moreover, these results were significantly higher than the positive controls selegiline (116 sec) and Aricept (127 sec; $\mathrm{P}<0.05)$. These results demonstrate that Chana 1 can improve $\mathrm{A} \beta$-induced learning and memory impairment in mice. During the study, all group of mice gained weight regularly (Table I).

Determination of the $L D_{50}$ of Chana 1 in mice. It is critical that an active compound has its safety assessed to be valuable for its biological efficacy. Thus, an oral acute toxicity test of Chana 1 was carried out. The $\mathrm{LD}_{50}$ of Chana 1 in mice was determined after a single oral administration. The behavior of the mice and number of deaths were observed for $96 \mathrm{~h}$. The effects of oral administration of a single dose of Chana 1 are summarized in Table II. We found a dose-dependent increase in mortality and adverse effects. The mortality rate increased to $60 \%$ at the highest dose tested $(700 \mathrm{mg} / \mathrm{kg})$ and males were more sensitive than females. We determined the latency of mortality and observed it up to $31 \mathrm{~h}$. The symptoms of toxicity, such as slow movement, hair bristling, lying down, and eye mucus were similar in both genders. From these data, we estimate the oral $\mathrm{LD}_{50}$ of Chana 1 in mice to be $520.44 \mathrm{mg} / \mathrm{kg}$ body weight.

\section{Discussion}

In the present study, we determined that the chalcone derivative, Chana 1 , has neuroprotective effects against $A \beta$-induced oxidative stress and memory impairment. Oxidative stress has consistently been implicated in the neuronal cell death and dysfunction observed in chronic neurodegenerative diseases, including Alzheimer's disease (AD) $(29,30)$. Furthermore, it is well known that the $A \beta$ peptide generates ROS directly inside cell membranes to cause protein oxidation and lipid peroxidation (31) as well as neuronal cell death (32). Oxidative damage is clear in the postmortem examination of brains from patients with $\mathrm{AD}$ due to the presence of oxidative DNA, lipid peroxidation, modification of proteins, and other indicators of ROS damage such as 4-hydroxy-2-trans-nonenal and malondialdehyde (33). Given the involvement of ROS in the pathogenesis of $\mathrm{AD}$, free radical scavengers and antioxidants have been suggested as possible therapies. In addition, many studies have reported that antioxidant activity reduces the neuronal cell death and memory impairment caused by A $\beta$ peptide (34-37).

Currently, there are two types of drugs on the market for AD: acetylcholinesterase inhibitors (e.g., Aricept, Tacrine) and N-methyl-D-aspartic acid receptor antagonists (e.g., Memantine). However, these drugs reduce the symptoms of the disease, rather than truly modifying the disease (38). Also, these drugs have negative side effects including nausea, vomiting, insomnia, orthostatic hypotension, and micturition dysfunction (39). Therefore, the search continues for more effective and less toxic therapies.

In a previous study, we determined that licochalcone derivatives, the Chana series, showed potential free radical scavenging activity. Chana 1 was one of the most potent free radical scavengers and we hypothesized it would be effective against $\mathrm{A} \beta$-induced neuronal damage.

Here, we demonstrated that Chana 1 has the ability to reduce $\mathrm{A} \beta$-induced neurotoxicity in $\mathrm{PC} 12$ cells. Treating mice with 20 or $50 \mathrm{mg} / \mathrm{kg}$ Chana 1 also ameliorated the impaired learning and memory as much as the positive control drugs. The antioxidant capacity of Chana 1 appears responsible for the neuroprotective effect due to the attenuation of oxidative stress. Moreover, the toxicity of Chana 1 was less than either selegiline or Aricept as measured by an acute toxicity test in mice. The $\mathrm{LD}_{50}$ value of Chana 1 was determined to be $520.44 \mathrm{mg} / \mathrm{kg}$ body weight, whereas the $\mathrm{LD}_{50}$ of selegiline was $385 \mathrm{mg} / \mathrm{kg}$ body weight (in the rat) (40) and the $\mathrm{LD}_{50}$ of Aricept was $45.2 \mathrm{mg} / \mathrm{kg}$ body weight (in mice) (41). According to the Hodge and Sterner scale (42), an $\mathrm{LD}_{50}$ within the range of $500-5000 \mathrm{mg} / \mathrm{kg}$ is considered slightly toxic (class 4), $50-500 \mathrm{mg} / \mathrm{kg}$ is considered moderately toxic (class 3), and $1-50 \mathrm{mg} / \mathrm{kg}$ is highly toxic (class 2). Thus, according to this scale, Chana 1 is considered less toxic than either selegiline or Aricept. Although chalcone derivatives receive attention due to their wide variety of pharmacological activities, there is no information on their safety or acute toxicity in vivo. Therefore, our acute toxicity study provides data for future clinical studies and information for the safe usage of chalcone derivatives.

In conclusion, we report that Chana 1 protects against $\mathrm{A} \beta$-induced oxidative stress and improves learning and memory impairment after $A \beta$ injection in mice. We suggest that the free radical scavenging activity of Chana 1 is responsible for its neuroprotective effects. Our results indicate that Chana 1 may be a promising agent to slow the progression of AD. Additionally, this study provides data on the acute toxicity of Chana 1 that could be useful for future studies.

\section{Acknowledgements}

This study was supported by a grant from the Korea Health Care Technology R\&D Project, Ministry for Health, Welfare and Family Affairs, Republic of Korea (A092039).

\section{References}

1. Huang X, Atwood CS, Jartshorn MA, et al: The A $\beta$ peptide of Alzheimer's disease directly produces hydrogen peroxide through metal ion reduction. Biochemistry 38: 7609-7616, 1999. 
2. Christen Y: Oxidative stress and Alzheimer disease. Am J Clin Nutr 71: S621-S629, 2000.

3. Floyd RA and Hensley K: Oxidative stress in brain aging. Implications for therapeutics of neurodegenerative diseases. Neurobiol Aging 23: 795-807, 2002.

4. Mattson MP, Chan SL and Duan W: Modification of brain aging and neurodegenerative disorders by genes, diet, and behavior Physiol Rev 82: 637-672, 2002.

5. Sultana R, Perluigi M and Butterfield DA: Oxidative modified proteins in Alzheimer's disease (AD), mile cognitive impairment and animal models of AD: role of $\mathrm{A} \beta$ in pathogenesis. Acta Neuropathol 118: 131-150, 2009.

6. Zhu X, Su B, Wang X, Smith MA and Perry G: Causes of oxidative stress in Alzheimer disease. Cell Mol Life Sci 64: 2202-2210, 2007.

7. Mark RJ, Lovell MA, Markesbery WR, Uchida K and Mattson MP: A role for 4-hydroxynonenal, an aldehydic product of lipid peroxidation, in disruption of ion homeostasis and neuronal death induced by amyloid $\beta$-peptide. J Neurochem 68 : 255-264, 1997.

8. Butterfield DA, Hensley K, Harris M, Mattson M and Carney J: $\beta$-amyloid peptide free radical fragments initiates synaptosomal lipoperoxidation in a sequence-specific fashion: implications to Alzheimer's disease. Biochem Biophys Res Commun 200: 710-715, 1994

9. Rahman I, Biswas SK and Kode A: Oxidant and antioxidant balance in the airways and airway diseases. Eur J Pharmacol 533: 222-229, 2006.

10. Butterfield DA and Sultana R: Methionine-35 of $\alpha \beta(1-42)$ : importance for oxidative stress in Alzheimer disease. J Amino Acids 2011: 198430, 2011.

11. Pappolla MA, Sos M, Omar RA, et al: Melatonin prevents death of neuroblastoma cells exposed to the Alzheimer amyloid peptide. J Neurosci 17: 1683-1690, 1997.

12. Bruce AJ, Malfroy B and Baudry M: $\beta$-amyloid toxicity in organotypic hippocampal cultures: protection by EUK-8, a synthetic catalytic free radical scavenger. Proc Natl Acad Sci USA 93: 2312-2316, 1996.

13. Bastianetto S, Ramassamy C, Doré S, Christen Y, Poirier J and Quirion R: The Ginkgo biloba extract (EGb 761) protects hippocampal neurons against cell death induced by $\beta$-amyloid. Eur J Neurosci 12: 1882-1890, 2000.

14. Oken BS, Storzbach DM and Kaye JA: The efficacy of Ginkgo biloba on cognitive function in Alzheimer disease. Arch Neurol 55: 1409-1415, 1998.

15. Cohen-Salmon C, Venault P, Martin B, et al: Effects of Ginkgo biloba extract (EGb 761) on learning and possible actions on aging. J Physiol Paris 91: 291-300, 1997.

16. Rice-Evans CA, Miller NJ and Paganga G: Structure-antioxidant activity relationship of flavonoids and phenolic acids. Free Radic Biol Med 20: 933-956, 1996.

17. Park HG, Bak EJ, Woo GH, et al: Licochalcone $E$ has an antidiabetic effect. J Nutr Biochem: Aug 11, 2011 (Epub ahead of print).

18. Lan YH, Liu YL, Peng YT, Thang TD, Lin CC and Bao BY: The first Bis-retrochalcone from Fissistigma latifolium. Planta Med 77: 2019-2022, 2011.

19. Haraguchi H, Tanimoto K, Tamura Y, Mizutani $\mathrm{K}$ and Kinoshita T: Mode of antibacterial action of retrochalcones from Glycyrrhiza inflate. Phytochemistry 48: 124-129, 1998.

20. Liu Z, Lee W, Kim SN, Yoon G, Cheon SH: Design, synthesis, and evaluation of bromo-retrochalcone derivatives as protein tyrosine phosphatase 1B inhibitors. Bioorg Med Chem Lett 21: 3755-3758, 2011.

21. Haraguchi $\mathrm{H}$, Ishikawa $\mathrm{H}$, Mizutani $\mathrm{K}$, Tamura $\mathrm{Y}$ and Jinoshita $\mathrm{T}$ : Antioxidative and superoxide scavenging activities of retrochalcones in Glycyrrhiza inflate. Bioorg Med Chem 6: 339-347, 1998.
22. Kim MJ,Lee YH, Kwak J, NA Y and Yoon HG: Protective effect of a chalcone derivative against $A \beta$-induced oxidative stress and neuronal damage. BMB Rep 44: 730-734, 2011.

23. Blois MS: Antioxidant determinations by the use of a stable free radical. Nature 181: 1199-1200, 1958.

24. Chauhan NB, Siegel GJ and Lichtir T: Distribution of intraventriculary administrated antiamyloid- $\beta$ peptide $(\mathrm{A} \beta)$ antibody in the mouse brain. J Neurosci Res 66: 231-235, 2001.

25. Yamaguchi Y and Kawashima S: Effects of amyloid $\beta$-(25-35) on passive avoidance, radial-arm maze learning choline acetyltransferase activity in the rat. Eur J Pharmacol 421: 256-272, 2001.

26. Shen Z, Wangn G and Linn SZ: Two-way shuttle box avoidance conditioning and brain NADH in rats. Physiol Behav 1: 165-211, 1990.

27. Organisation for Economic Co-operation and Development (OECD): OECD Guideline for Testing of Chemicals, Number 420. Acute Oral Toxicity: fixed dose procedure. OECD, Paris, 2001.

28. Jung JC, Jang S, Lee Y, et al: Efficient synthesis and neuroprotective effect of substituted 1,3-diphenyl-2-propen-1-ones. J Med Chem 51: 4054-4058, 2008.

29. Heneka MT, O'Banion MK, Terwel D and Kummer MP Neuroinflammatory processes in Alzheimer's disease. J Neural Transm 117: 919-947, 2010.

30. Kim MJ, Seung AR, Yoo JY, et al: Gallic acid, a histone acetyltransferase inhibitor, suppresses $\beta$-amyloid neurotoxicity by inhibiting microglial-mediated neuroinflammation. Mol Nutr Food Res 55: 1798-1808, 2011.

31. Varadarajan S, Yatin S, Aksenova M and Butterfield DA. Review: Alzheimer's amyloid beta-peptide-associated free radical oxidative stress and neurotoxicity. J Struct Biol 130: 184-208, 2000.

32. Kadowaki H, Nishitoh H, Urano F, et al: Amyloid beta induces neuronal cell death through ROS-mediated ASK1 activation. Cell Death Differ 12: 19-24, 2005.

33. Bonda DJ, Wang X, Perry G, Numonura A, Tabaton M, Zhu X and Smith MA: Oxidative stress in Alzheimer disease; a possibility for prevention. Neuropharmacololgy 59: 290-294, 2010.

34. Park SY, Kim HS, Cho EK, Kwon BY, Phark SH, Hwang KW and Sul DG: Curcumin protected PC12 cells against beta-amyloid induced toxicity through the inhibition of oxidative damage and tau hyperphosphorylation. Food Chem Toxicol 46: 2881-2887, 2008.

35. Yazdanparast $\mathrm{R}$ and Shaykhalishahi $\mathrm{H}$ : Protective effect of triazine-derivative (AA3E2) on $\beta$-amyloid-induced damages in SK-N-MC cells. Toxicol In Vitro 23: 1277-1283, 2009.

36. Fu AL, Dong ZH and Sun MJ: Protective effect of N-acetyl$\mathrm{L}$-cystein on amyloid $\beta$-peptide-induced learning and memory deficits in mice. Brain Res 1109: 210-216, 2006.

37. Mishra S, Mishra M, Setj P and Sharma SK: Tetrahydrocurcumin confers protection against amyloid $\beta$-induced toxicity. Neuroreport 22: 23-27, 2011.

38. Mangialasche F, Solomon A, Winblad B, Mecocci P and Kivipelto M: Alzheimer's disease: clinical trials and drug development. Lancet Neurol 9: 702-716, 2010.

39. Riederer P and Laux G: MAO-inhibitors in Parkinson's disease. Exp Neurobiol 20: 1-17, 2011

40. The Merck Index Online, file 304, 2009. http://library.dialog. com/bluesheets/pdf/bl0304.html.

41. Pfizer, Inc.: Aricept: Material Safety Data Sheet. Version 4.0. Pfizer Global Environment, Health and Safety Operations. New York, 2010. http://www.pfizer.com/files/products/material_ safety_data/296.pdf.

42. Canadian Centre for Occupational Health and Safety (CCOHS): What is an LD50 and LC50. CCOHS, 2005. http://www.ccohs. ca/oshanswers/chemicals/Id50.html. 